\title{
Elinikäisen oppimisen Panopticon
}

ANTTI SAARI

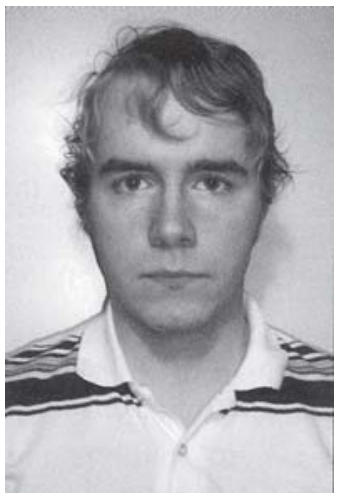

Kirjoittaja tuo elinikäisestä oppimisesta käytyyn kriittiseen keskusteluun sitä täydentävän, valtateoreettisen näkökulman, joka nojaa Michel Foucaultin ja foucault laisten kasvatustieteilijöiden tuotantoon. Tätä foucault’laisen elinikäisen oppimisen analyysiä hän luonnehtii Kenneth Wainia lainaten epäilyn politiikaksi. Se etsii vallankäyttöä juuri sieltä, missä sen olemassaolo vahvimmin kielleltään. Elämme modernissa Panopticon-yhteiskunnassa, jonka tarkoituksena on tuottaa ja lisätä yksilön hyödyllisiä voimia ja joka hyvää elämää määritellessään ulottuu myös yksityisen elämän alueelle.
Elinikäistä oppimista koskevassa keskustelussa viitataan usein yhteiskunnassa muutaman viime vuosikymmenen aikana tapahtuneisiin murroksiin ja katkoksiin. Vanhan palkkatyöhön perustuvan hyvinvointiyhteiskunnan olemassaolon edellytykset ovat murtuneet ja globaali talous on muuttanut työmarkkinoita entistä epävakaisemmiksi ja vaikeammin hallittaviksi. Samoin työn luonne on muuttunut aiempaa informaatiopainotteisemmaksi. Tietoyhteiskunnassa informaation tuottamisen, hallinnan, levittämisen ja pääomaksi muuntamisen prosessit muodostavat olennaisen osan kansakunnan kilpailukyvystä. (Wain 2004; Rinne \& Salmi 1998, 122-124)

Yksilön elämässä nämä muutokset näkyvätentistä fragmentoituneempana elämänkaarena. Selkeän nuoruuden koulutusjakson ja sitä seuraavan palkkatyövaiheen ja lopulta eläkkeen sijasta sitä hallitsevat nyt lyhyet työssäolojaksot, uudelleenkouluttautumisen vaiheet ja usein myös ajoittainen työttömyys. (Rinne 1998, 115-116) Vaikka murrokset tuovat elämään epävarmuutta ja uhkatekijöitä, uusi työn yhteiskunta tuo yksittäiselle inmiselle myös vapautta useina valinnan vaihtoehtoina, joista koota oma työuransa ja identiteettinsä. (Rinne \& Salmi 1998, 130-133; Rinne 1998, 114-116; Tuomisto 2002, 20-21)

Tämä katkosdiskurssi näyttää legitimoivan elinikäistä oppimista koskevaa koulutuspolitiikkaa ja tutkimusta. (Edwards, Ranson \& Strain,
2002) Alituisessa muutoksessa olevat työmarkkinat ohjaavat huomiota yksilön uudelleenkouluttautumisen valmiuksiin ja kykyyn päivittää osaamistaan. Informaatioyhteiskunta vaatii myös ajattelemaan uudelleen koulutuksen ja oppimisen käsitteitä. Koska koulutus ei voi tänä päivänä valmistaa yksilöitä ainoastaan yhteen ammattiin ja rajatulle asiantuntijuuden alueelle, koulutuksen sijasta painotetaan nyt oppimista, yksilön yleistä kykyä sopeutua jatkuviin muutoksiin työelämässä ja tuottaa uusia ratkaisuja elämänhallintaansa. (Edwards, Ranson \& Strain, 2002)

Vaikka elinikäinen oppiminen esitetään usein lääkkeenä yhteiskunnallisiin epäkohtiin, toisinaan nähdään myös, että elinikäisen oppimisen pinnan alta paljastuu uusliberalistinen koulutuspolitiikka. Siinä missä Suomen, EU:n ja OECD:n koulutuspoliittinen retoriikka painottaa yksilön autonomiaa, oma-aloitteisuutta ja valinnan mahdollisuuksia, muuttuneen yhteiskunnan riskit kasataan käytännössä pitkälti yksilön harteille vähentämällä koulutusinstituutioiden ja yhteiskunnan vastuuta. (Tuomisto 2002; 2004; Rinne 2004)

Uusliberalistiseen elinikäisen oppimisen retoriikkaan näyttää kuuluvan myös markkinalogiikan tuominen koulutuspolitiikkaan. Aikuisoppija nähdään nyt yrittäjänä, joka pyrkii selviytymään työmarkkinoilla koulutuksessa hankkimillaan henkilökohtaisilla kompetensseilla ja oppi- 
misen taidoilla. Koulutuksesta on toisin sanoen tullut hyödyke. Samalla perinteinen aikuiskasvatus kansansivistyksellisine periaatteineen on muuttumassa uusien työmarkkinoiden ohjaamaksi elinikäiseksi oppimiseksi (Rinne 2004, 236238; Peters 2001)

\section{Hallinta, tieto, subjektivaatio}

Edellä kuvattu teoreettinen keskustelu pohjautuu siis näkemykseen laajasta yhteiskunnallisesta murroksesta, siirtymästä myöhäismoderniin yhteiskuntaan tai informaatioyhteiskuntaan, joka on tuonut mukanaan uudenlaisen ymmärryksen aikuiskoulutuksesta elinikäisen oppimisen muodossa. Muutokset sisältävät yksilön elämään liittyviä uhkia, mutta toisaalta myös uudenlaista vapautta ja valinnan mahdollisuuksia.

Pyrkimättä kyseenalaistamaan tätä näkökulmaa tarkoituksenani on Michel Foucault'n ja foucault'laisten kasvatustieteilijöiden tuotantoon nojaten tuoda täydentävä, valtateoreettinen näkökulma elinikäisen oppimisen kriittiseen analyysiin. Sen avulla voidaan luoda kuva elinikäisen oppimisen hallinnasta, joka peittää vallankäyttönsä vapaiden ja yritteliäiden yksilöiden ja tieteellisen asiantuntijatiedon taakse. Analyysi tapahtuu kolmen toisensa risteävän ulottuvuuden, tieteellisen tiedon, hallinnan ja subjektivaation muotojen viitekehyksessä. (ks. Foucault 1999, 117-120; Hacking 2002, 3; Heikkinen, Silvonen \& Simola 1999; Popkewitz 1999; Rose 1996) Kyseisen hahmotustavan avulla voidaan kysyä, millä tavoin asiantuntijatieto tekee näkyväksi hallinnan kannalta relevantteja kohteita ja päämääriä, sekä miten subjektit muotoutuvatelinikäisinä oppijoina suhteessa yhteiskunnallisen hallinnan mentaliteettiin ja aikuiskasvatukselliseen asiantuntijatietoon.

Näen, että tämä heterogeenisia elementtejä yhdistelevä näkökulma tuo esiin uudenlaisia aineksia elinikäisen oppimisen politiikan analyysiin. Se ei pyri pakottamaan elinikäistä oppimista yhteen sitä ohjaavaan instanssiin tai intressiin, vaan tuo sen esiin levittäytyneenä useisiin pedagogisiin instituutioihin ja käytäntöihin. Se ei myöskään sitoudu makro- tai mikrososiologiseen näkökulmaan, vaan pyrkii tuomaan yhteen elinikäisen oppimisen yhteiskunnan rakenteisiin siinä missä yksilön toimintaankin liittyvät aspektit. Se olettaa lähtökohtaisesti, että elinikäiseksi oppijaksi nimetty yksilö ei ole koulutuspoliitti- sen hallinnan ja asiantuntijatiedon ulkopuolelle asettuva olento, jonka jo olemassa olevia toimintaedellytyksiä hallinta tukee, vaan hallinnalle ja tiedolle sisäinen subjekti.

Foucault'laisen valta-analytiikkaa koskeva keskustelu on aikuiskasvatuksen alueella ollut ainakin Suomessa toistaiseksi melko vähäistä. Olemassa olevasta kansainvälisestä keskustelusta viittaan aluksi kasvatusfilosofi Kenneth Wainin (2004) foucault'laiseen analyysiin elinikäisen oppimisen yhteiskunnasta. Wain ottaa mallikseen Foucault'n idean Panopticonista, modernin aikakauden yksilöihin kohdistuvan pedagogisen hallinnan ja ihmistieteellisen tiedonmuodostuksen apparaatista, ja katsoo sen soveltuvan myös elinikäisen oppimisen ideologiaan ja käytäntöihin. Tämä teoreettinen viitekehys herättää epäilyn, ovatko näkemykset viimeaikaisista yhteiskunnallisista murroksista ja yhteiskunnan uudenlaisesta hallinnasta osittain vailla pohjaa hallinnan muodon, tiedon ja subjektivaation ulottuvuuksien keskinäisten suhteiden pysyessä samana.

Täydennän Wainin näkemyksiä muun muassa Richard Edwardsin (2004) foucault'laisella analyysillä eurooppalaisesta elinikäisen oppimisen politiikasta ja tutkimuksesta. Lopuksi ehdotan Nikolas Roseen (1999;1996) ja Gilles Deleuzeen (2005) tukeutuen, että elinikäisen oppimisen diskurssi heijastelee myös muutoksia yhteiskunnallisen vallankäytön muodoissa. Pedagogisiin instituutioihin sitoutuneesta kurinpidollisesta vallasta on siirrytty kohti entistä vaikeammin havaittavaa, minimalistista oppimisen hallintaa, jossa yksilöiden nähdään hallitsevan itse itseään, asettavan omaehtoisia tavoitteita ja toteuttavan omia oppimisen tarpeitaan. Aikuisen oppiminen ja sen hallinnointi siirtyy entistä selkeämmin pois oppimista ennen tuottaneista laitoksista. Tämän tuloksena tavat kuvata ja hallita oppimista ja elinikäisen oppijan identiteettiä ovat entistä abstraktimpia ja liikkuvampia ja ne kattavat koko ihmiselämän.

\section{Kurinpidollinen valta ja biovalta}

Kirjassaan Tarkkailla ja rangaista (1980, 225-231) Michel Foucault esittää kuuluisan analyysinsä englantilaisen filosofin Jeremy Benthamin suunnittelemasta Panopticon-rangaistuslaitoksesta. Vangit elivät tämän kehämäisen rakennuksen selleissä eristettyinä kaikista sosiaalisista kontak- 
teista. Vartija pystyi vankilan keskustassa olevasta tornista näkemään täydellisesti jokaisen vangin liikkeen, mutta samanaikaisesti piiloutumaan siten, ettei vanki pystynyt tietämään, koska häntä tarkkailtiin. Tämä asetelma mahdollisti paitsi vankien jatkuvan tarkkailun ja pienimpienkin toiminnan yksityiskohtien ohjaamisen, myös vankien sielunelämän dokumentoinnin ja muokkaamisen. Vanki tunsi olevansa kaiken aikaa tarkkailun ja ohjauksen kohteena ja alkoi tämän tuloksena ohjailla omaa toimintaansa normaalistavan katseen mukaisesti. Kun valvova katse piiloutui fyysisesti, se siirtyi vallankäytön kohteen sisäiseksi kuriksi.

Foucault'n mukaan tämä nerokas vallan ja tiedon arkkitehtuuri siirtyi nopeasti myös muihin moderneihin kurinpidollisiin instituutioihin, kuten tehtaaseen, armeijaan, sairaalaan ja kouluun. Nämä uudet instituutiot olivat paitsi kurinpidollisen vallan, myös inmistieteellisen tiedonmuodostuksen tekniikoiden - kriminologian, psykologian ja pedagogian syntysijoja. Ne keskittyivät yksilön läpitunkevaan dokumentointiin ja toiminnan tehostamiseen kehittämällä yksilön funktionaalisia voimia ja vaimentamalla yhteiskunnallisesti vaarallisia tai hyödyttömiä piirteitä. Ihmistieteellinen asiantuntijatieto osallistui tällä tavoin normaalistavaan toimintaan, jonka avulla yksilö pyrittiin sopeuttamaan yhteiskuntaan työmoraalin ja työelämässä tarvittavien taitojen kehittämisen muodossa. (Foucault 1980)

Kurinpidollisen vallan ja sitä edistävän ihmistieteellisen tiedontuotannon alojen lisäksi kehittyi myös toisenlainen, ihmisen elämään kokonaisuudessaan kohdistuva moderni vallan muoto, biovalta. Sen tarkoituksena oli tarkastella yhteiskuntaa populaationa; tehdä näkyväksi ja hallittavaksi yksityisen inmiselämän koko alue - varallisuus, syntyvyys ja kuolleisuus, sairauden, rikollisuuden ja seksuaalisuuden eri muodot. Tätä kautta se pyrki luomaan edellytyksiä hyvälle elämälle niin yksittäisen kansalaisen kuin populaationkin tasolla. (Foucault 1999, 98-103)

Ihmiselämän tuominen näiden vallan muotojen piiriin oli myös teollisen yhteiskunnan kehittymisen ennakkoehto, sillä ruumiin niveltäminen kurinpidollisesti osaksi tuotantokoneistoa sekä elämän voimien valjastaminen työvoimaksi oli välttämätöntä tuotannon tehokkuuden kannalta. (Foucault 1999, 141; 2003) Tämänkaltainen kurinpidollisen vallan ja biovallan yhdistelmä muodosti välttämättömän vastinparin liberaa- lille demokraattiselle yhteiskunnalle, piirtäen sen kansalaisten vapauden rajat ja ehdot, sekä mahdollistaen sen hyvinvoinnin, vakauden ja jatkuvuuden. (Wain 2004, 285) Modernin vallan muotojen sekä demokratian ihanteiden yhteinen kehitys tuotti lisäksi nykypäivänäkin vallitsevan hallinnan dilemman, jossa tunnustetaan tarve yhteiskunnan aktiiviseen hallintaan sen järjestyksen ja hyvinvoinnin turvaamiseksi, mutta toisaalta pyritään myös turvaamaan kansalaisten itsemääräämisoikeus ja yksityisyyden alue. (Helén 2004; Wain 2004)

Vaikka toisinaan puhutaankin sarkastisesti elinikäisen oppimisen vankilasta, on ehkä vaikeaa kuvitella, että ainakaan kyseinen kurinpidollisten instituutioiden hallinnan muoto koskisi aikuisten oppimista. Elinikäisen oppimisen lähtökohtana on tunnetusti autonominen, itseään hallitseva aikuinen yksilö, jonka elämänsuunnitelmia elinikäisen oppimisen käytänteet pyrkivät tukemaan. Vankilassa tai kansakoulussa tapahtuvaa vallankäyttöä voidaan näin ollen tuskin samaistaa elinikäisen oppimisen keskeisiin periaatteisiin ja toimintatapoihin - kriitikoiden soraäänistä huolimatta. Tässä kohtaa on kuitenkin huomattava, millä tasolla Foucault'n valtaanalytiikka liikkuu.

Hallinta modernissa yhteiskunnassa ei ole jotakin, joka kohdistuu vapaiden yksilöiden intressejä vastaan.(Foucault 1999, 63-76; Rose 1996, 151-166) Foucault'n kuuluisa hämmentävä väite on, että valta tuottaa subjektin ja hänen intressinsä, jopa hänen mahdollisuutensa toimia autonomisesti. Se ei ole aikuisellekaan subjektille ulkoista, vaan erityisesti subjektia konstituoivaa ja sisäisessä yhteydessä subjektin intresseihin. Näin ollen se on kytköksissä ihmisen tapaan ymmärtää ja kehittää itseään, jopa hänen vapauteensa

On myös huomattava, että valtarakenteet kaikessa yleisyydessään eivät asetu tieteellistä tietoa vastaan. Tieto ei foucault'laisessa viitekehyksessä ole vallasta vapaa, vaan aina instrumentti, jolla on kyky luoda tilaa vallankäytölle, tehden sen kohteen näkyväksi ja hallittavaksi. Myös vallan ja tiedon välillä on toisin sanoen sisäinen suhde. Näistä lähtökohdista muodostuu Foucault'lle ominainen valta-analytiikka (1999, 62-63), joka tarkastelee hallinnan tekniikoiden, tiedonmuodostuksen ja subjektivaation muotojen yhteistä toimintaa. ${ }^{1}$ 


\section{Elinikäisen oppimisen Panopticon}

Kenneth Wainin (2004, 181-187) mukaan nykyistä elinikäisen oppimisen yhteiskuntaa voidaan kaikista viimeaikaisista katkospuheista huolimatta nimittää juuri moderniksi Panopticon-yhteiskunnaksi. (ks. myös Lambeir 2005, 352; Brookfield 2005, 132-139) Sen hallinnan muoto koostuu useista yksilöinnin ja sopeuttamisen menetelmistä, jotka hyödyntävät inmistieteellistä asiantuntijatietoa toimiakseen tehokkaasti ja legitiimisti. Sen tarkoituksena on yksilön hyödyllisten voimien tuottaminen ja lisääminen, sekä yhteiskunnan toiminnalle haitallisten voimien tukahduttaminen. Biovallan tavoin se levittäytyy ottamaan haltuunsa myös ihmisen yksityisen elämän alueet, kantaen huolta yksityisen ihmisen elämänsuunnitelmien toteutumisesta sekä koko yhteiskunnan toimimisesta tehokkaasti yhteiskunnallisten muutosten keskellä. Se osallistuu jopa hyvän elämän määrittelyyn ja rajaamiseentässäajassa.

Kyseessä ei ole helposti osoitettava, yhdestä hallinnallisesta instituutiosta yhteiskuntaan levittäytyvä hallinnan muoto, vaan hajanainen, yksityiskohtainen ja yhä uudestaan piiloutuva valta. Se käyttää julkista, yhteisöllistä ja kriittistä asiantuntijatietoa, tukeutuu liberaaleihin vapauden ja autonomian ideaaleihin ja pyrkii muotoutumaan osaksi subjektin itseymmärrystä ja tapaa tarkastella elämäänsä objektiivisesti.

Edwardsin (2004) ja Lambeirin (2005) mukaan EU:n ja OECD:n kaltaisten instituutioiden keskeinen elinikäisen oppimisen problematisaatio on, kuinka hallita yhteiskuntaa sen yksilöiden kautta; miten yhdistää sekä yksilön ja yksityisyyden sekä markkinaperiaattein toimivan informaatioyhteiskunnan alueet tavalla, joka ei kuitenkaan ole yksilölle pakottavaa, vaan pikemminkin kannustavaa ja uusia mahdollisuuksia luovaa. Tästä syystä elinikäisellä oppimisella katsotaan olevan laajoja koulutuspolitiikan ulkopuolelle ulottuvia yhteiskuntapoliittisia merkityksiä. (ks. esim. Komiteanmietintö 1997, 26) Se nähdään yleisenä avaimena yksilön yhteiskunnallisiin muutoksiin sopeutumiseen sekä työelämän ja koulutuksen raja-aitojen rikkomiseen (ks. esim. OECD 1996) Elinikäisen oppimisen ohjelma kykenee edistämään yksilöiden henkilökohtaista kehittymistä ja aloitteellisuutta, heidän työelämään ja yhteiskuntaan sopeutumistaan, osallistumista demokraattisiin päätöksentekoproses- seihin sekä kykyä sopeutua taloudellisiin ja sosiologisiin, sekä teknologian alalla tapahtuviin muutoksiin. (Komiteanmietintö 1996, 34)

Elinikäinen oppiminen kytketään inhimilliseen olemassaoloon niin tiukasti, että se ymmärretään universaalina perusoikeutena, jota koulutuspolitiikan on tuettava (Komiteanmietintö 1996, 39-40) Merkittävää näissä huomioissa ei mielestäni ole se, millä tavoin suuret koulutuspolitiikkaan vaikuttavat instituutiot kierrättävät muodikasta uusliberalistista retoriikkaa, vaan se, kuinka ne onnistuvat kirjautumaan osaksi sitä laajaa ja yksityiskohtaista strategiaa, jolla valtarakenteet kietoutuvat huomaamattomaksi osaksi yksilön omia intressejä, motivaatiota ja työmarkkinoiden muutoksissa selviämisen edellytyksiä. Tässä biovalta näyttäytyy paljaimmillaan. Elinikäinen oppiminen laajentuu vaivihkaa koskemaan koko yhteiskuntaruumiin hallintaa - kaiken inhimillisesti arvokkaan puolustamista ja suojelemista. Tämä ei kuitenkaan tapahdu aggressiivisella byrokraattisella ohjailulla, vaan vetoamalla yhteiskunnassa ja yhteiskunnassa jo valmiina esiintyviin piirteisiin; työelämän ja yhteiskunnan muutospaineisiin, yksilön sisäiseen motivaatioon ja uusien asioiden oppimisen tarpeeseen, jotka toimivat kunkin yksilön henkilökohtaisena voimavarana muutosten keskellä. (ks myös Komiteanmietintö 1997, 24-26)

Foucault'laisessa tarkastelussa huomiota tulee kiinnittää myös siihen, miten elinikäisen oppimisen hallinnan ontologia ja sen normatiiviset piirteet luovat tietynlaisen näkyvyyden järjestelmän (ks. Rose 1996, 60-62) aikuisen oppijan tieteelliselle tarkastelulle, ja millä tavoin aikuiskasvatuksellinen asiantuntijatieto osallistuu koulutuksen hallinnallisiin problematisaatioihin. Edwardsin (2004) mukaan tutkimus jakaa usein hallinnan mentaliteetin kanssa samat ontologiset ja normatiiviset olettamukset aikuisoppijasta. Elinikäinen oppija aikuisena yksilönä, oppimaan motivoituneena, kompetensseja muodostavana, omaa toimintaansa reflektoivana ja tavoitteita asettavana olentona, rakennetaan erinäisten tieteellisten diskursiivisten käytäntöjen muodostamassa kokonaisuudessa, jonka tarkoituksena on tehdä inhimillinen toiminta näkyväksi ja hallittavaksi. Tutkimuksessa se kuitenkin esitetään maailmassa jo valmiina olevana luonnollisena kohteena, jota tutkimus kuvaa neutraalilla tavalla. (Edwards 2004) Tutkimuksen kohteen muodostamista varten elinikäisen oppimisen tutkimus 
mobilisoi tiedontuotannon tapoja yhteiskuntatieteiden ja taloustieteiden alueilta. Yhteiskuntatieteitä soveltamalla aikuiskasvatuksellinen tutkimus pyrkii kuvaamaan ja kehittämään yksilön sisäsyntyisiä kehittymisen potentiaaleja, yhteiskunnallista osallistumista, motivaatiota ja kognitivisia potentiaaleja. Samalla se kuitenkin irrottaa yksilön elinikäisenä oppijana sosiokulttuurisesta kontekstistaan - yhteiskuntaluokasta, sukupuolesta ja etnisestä identiteetistä. Taloustieteellinen diskurssin kautta puolestaan kuvataan elinikäistä oppimista erinäisten kompetenssien hankkimisena, jotka toimivat työmarkkinoilla pääoman tavoin, ja jotka tuottavat lisäarvoa myös koko yhteiskunnalle. (Edwards 2004, 7074) Tällä tavoin tutkimus kykenee menestyksekkäästi yhdistämään yhteiskunnan eri alueet hallinnan kannalta mielekkäällä tavalla. Se saattaa inmisen yksityisen elämän osaksi kaikille yhteistä vapauden ja onnellisuuden tavoittelua sekä samalla niveltää sen muuttuvien työmarkkinoiden toimintaan.

Elinikäinen oppiminen käsitteenä kantaa sisällään myös vahvasti normatiivisia piirteitä. Koska oletetaan lähtökohtaisesti, ettei nyky-yhteiskunnassa ole mahdollista pärjätä ilman jatkuvaa oppimista, edellä kuvatuista elinikäisen oppimisen piirteistä - joustavuudesta, yrittäjähenkisyydestä ja itsenäisten valintojen tekemisestä - tulee jokaisen kansalaisen hyvän elämän ennakkoehtoja, joita hallinnan ja tutkimuksen avulla pyritään edistämään. (Edwards 2004, 76; Lambeir 2005)

\section{Totuus itsestä}

Valtarakenteet eivät kuitenkaan tule toimiviksi pelkästään koulutuspoliittisten päättävien elinten ohjelmanjulistuksissa tai ihmistieteellisissä diskursseissa. Hallinnan tehokkuuden ja tutkimuksen legitimiteetin kannalta on olennaista, että edellä kuvatut diskursiiviset tekniikat onnistuvat vakauttamaan kohteensa. Tämä onnistuu parhaiten silloin, kun hallinnan normit sisäistyvät osaksi subjektin itseymmärrystä ja itsensä kehittämistä. Foucault'n (1999) mukaan subjektivaation muodot tulevat näkyviksi niissä sangen arkipäiväisissä tavoissa, joilla yksilö houkutellaan puhumaan totuus itsestään, tarkastelemaan itseään julkisesti. Puhumalla itsestään ihminen samalla tuottaa uudelleen omaa minuuttaan. (ks. myös Hacking 2002, 116-17; Rose 1990, 240)
Hallinnan normien sisäistäminen saavutetaan yleisestä uskosta siihen, että tieteellisen asiantuntijatiedon avulla yksilö pystyy asettumaan ikään kuin itsensä ulkopuolelle ja näkemään itsensä yleisestä näkökulmasta. (Dreyfus \& Rabinow 1982, 175)

Aikuiskasvatukselliset käytännöt ovat tulvillaan erinäisiä itsearvioinnin ja -hallinnan menetelmiä; ohjauskeskusteluita, henkilökohtaisia opintosuunnitelmia, arviointilomakkeita, oppimispäiväkirjoja ja portfolioita, jotka kaikki omalla tavallaan materialisoivat panoptisen valvonnan idean. (ks. Brookfield 2005, 134-137; Tennant 1998) Nämä voidaan tietysti asettaa palvelemaan mitä erilaisempia terapeuttisia tarkoitusperiä työelämän laadun parantamisesta sukupuoliseen emansipaatioon. Yhteistä näille tekniikoille on kuitenkin transformatiivinen intressi, jossa nähdään, että yksilö voi löytää todellisen minuutensa ja muuttaa omaa elämänsä kohdistamalla terapeuttinen asiantuntijadiskurssi omaan sisäisyyteensä. (ks. Rose 1990, 243-246)

Elinikäisen oppimisen diskurssissa oletetaan usein, että aikuisella oppijalla on luontainen kyky reflektoida, tarkastella omia kokemuksiaan rationaalisesti suhteessa toimintansa tavoitteisiin. Se siis viittaa eräänlaiseen subjektin kahtiajakautumiseen, jossa ihminen on samanaikaisesti sekä tarkkailija että tarkkailtu. Reflektio yleisinhimillisenä prosessina on läsnä sekä formaalin koulutuksen että arkielämän alueella. Se sisältää subjektin toiminnan kokonaisuudessaan - niin kognitiiviset, emotionaaliset kuin ruumiillisetkin ulottuvuudet (ks. esim. Boud, Keogh \& Walker 1989) Yksilö voi tehdä reflektiivisen toimintansa näkyväksi itselle tai muille erinäisin kirjoittamisen tai vuoropuhelun tekniikoin, joissa hän objektivoi oman kokevan sisäisyytensä asettamalla toimintansa näkyviin kriittisen ja vertailevan katseen alle. Reflektion teknologia ei kuitenkaan tee näkyväksi sitä, miten itse terapeuttisen diskurssin mukaisesti toimeenpantu reflektio, omaan itseen kohdistuva viileän arvioiva katse, ja jopa sen mahdollistava autonominen subjekti, ovat sosiaalisessa viitekehyksessä rakentuneita entiteettejä. Sen sijaan se esittää reflektiokyvyn kontekstittomana rationaalisena toimintana, joka on tunnistettavissa kaikissa inhimillisen toiminnan muodoissa. (Erlandson 2005)

Tämänkaltaisten subjektin sisäisyyteen kohdistuvien tekniikoiden kautta autonomian, vapauden ja yksilöllisyyden alueesta tulee osa elin- 
ikäisen oppimisen hallinnan kenttää. Yksilö houkutellaan näkemään itsensä tavoiteorientoituneenaja itseään alati kehittävänä oman onnensa seppänä. Jokisaaren (2004, 10-12) mukaan tämänkaltaisen etiikan sisäistyminen pitää persoonan jatkuvassa liikkeessä. Elinikäinen oppija on näet määritelty vajavuutena, jatkuvana keskeneräisyytenä suhteessa muuttuviin yhteiskunnan vaatimuksiin, mikä pakottaa hänet yhä uudelleen kehittämään ominaisuuksiaan. (ks. myös Lambeir 2005; Virtanen 2006, 256) Samalla voidaan osittain rajata yksilön mahdollisuuksia asettua vastarintaan, sillä elinikäinen oppija tulee tiedollisesti eristetyksi kaikista niistä sosiaalisista, kulttuurisista ja poliittisista voimista, jotka hänen itseymmärrykseensä vaikuttavat. (Erlandson 2005, 666) Epäonnistuessaan yksilö voi ainoastaan katsoa peiliin ja kritisoida itseään. Juuri tällä tavalla hallinta voi toimia etäältä ja huomaamatta; naamioimalla hallinnan keinot subjektin objektiivisiksi ja käytännöllisiksi tavoiksi tunnistaa itsensä. Samalla se tuottaa yhden ratkaisun hallinnan tarpeiden sekä yksilön vapauden ja vastuullisuuden kunnioittamisen väliseen dilemmaan. Elinikäisen oppimisen hallinta ei näet ole avointa tyranniaa, vaan päinvastoin täysin demokraattisten ja liberaalien arvojen mukaista sen kiinnittyessä aikuiseen, itseohjautuvaan, vapaaseen subjektiin (Lambeir 2005, 352)

\section{Hallinta etäältä}

Kenneth Wain (2004) näkee elinikäisen oppimisen ideologiassa ja käytänteissä modernin hallinnan apparaatin, Panopticonin, joka kohdistuu yksilöihin ja heidän toimintaansa. Se käyttää ihmistieteellistä asiantuntijatietoa tehdäkseen kohteensa näkyväksi ja hallittavaksi. Tieteellinen diskurssi puolestaan sisäistyy osaksi elinikäisen oppijan itseymmärrystä ja toimintaa. Näin ollen voitaisiin olettaa, että siinä missä elinikäisen oppimisen diskurssin yhteydessä korostetaan usein yhteiskunnallisia katkoksia siirtymänä teollisesta yhteiskunnasta ja hyvinvointivaltiosta informaatioyhteiskuntaan ja uusliberalistiseen hallintaan, foucault'lainen valta-analytiikka tuo esiin elinikäisen oppimisen hallinnan jatkuvuuden modernina vallankäyttönä. (ks. esim. Fejes 2005) Toisaalta on selvää, että kyseisen viitekehyksen pohjalta voidaan tarkastella myös hallinnan erityispiirteitä tässä ajassa.

Kommentoidessaan Foucault'n valta-analy- tiikkaa Gilles Deleuze (2006) toteaa, että tieto, hallinta ja subjektivaation muodot ovat nykyyhteiskunnassa vapautumassa institutionaalisista rajoitteistaan. Hallinta ei tänä päivänä tapahdu olennaisesti institutionaalisessa tilassa, jossa suorituksia kontrolloidaan tiukkojen normien ja rajattujen tavoitteiden mukaisesti. Elinikäiseen oppijaan kohdistuva valta ei ole tällä tavalla normaalistavaa tai kurinpidollista. Sen sijaan hallinnalliset teknologiat siirtyvät kontekstista toiseen entistä helpommin, sillä puhumalla muutoksesta, joustavuudesta ja yrittäjähenkisyydestä ne sisältävät yhä abstraktimpia ja entistä enemmän yksilön mieleen viittaavia hallinnan kohteen kuvaamisen keinoja. Tällä tavoin biovalta löytää yhä uusia alueita, joilla purkaa yksityisen ja julkisen välinen erottelu. (Peters 2001, 60)

Individualististen painotusten myötä oppiminen on nykyisessä aikuiskasvatuksen diskurssissa muodostumassa koulutuksen sijaan keskeiseksi kategoriaksi (Edwards 2004, Tuomisto 2004, 70) Lisäksi oppimisen käsite on saanut yhä laajemman alan, joka kattaa myös non-formaalit ja informaalit inhimillisen toiminnan alueet.

Lambeir väittää, että koska oppimisen käsite ei myöskään ole enää sidoksissa tiettyyn tarkoitukseen, tilanteeseen tai instituutioon, korostuu oppimisen luonne prosessina, yleisenä funktiona suhteessa "muutokseen", "autonomiaan" ja "reflektioon", yhtä lailla yleisluontoisiin ilmiöihin, joilla ei ole olemassa erityistä paikkaa tai aikaa. (Lambeir 2005) Hallinnan rationaliteetti ei myöskään enää pyri muovaamaan yksilön olemassaoloa tiettyyn muottiin - oppilaaksi, työläiseksi tai alemmaksi toimihenkilöksi, sillä fragmentoitunut elämä ei salli rajoittuneita identiteettejä. Siksi hallinta kohdistuu yksilöön kaikessa yleisyydessään; elinikäinen oppija on nyt oppija sekä yrittäjä, jonka toimintaa voidaan kuvata yhtäläisesti millä tahansa yhteiskunnan alueella (Deleuze 2006). Elinikäisen oppimisen kytkeytyminen yksilön henkilökohtaisiin ominaisuuksiin toimii myös informaatiotalouden toiminnan keskeisenä ehtona. Koska kansakuntien kilpailukyvyn ylläpidon keskeisenä tekijänä pidetään informaatiota ja henkistä työvoimaa, muodostuvat kansalaisten oppimisen, informaation ja innovaatioiden tuottamisen kyvyt keskeisiksi ominaisuuksiksi. (Rose 1999, 162; Lambeir 2005; Virtanen 2006, 253-255.) ${ }^{2}$

Samalla hallinta on löytänyt uusia keinoja tehdä itsensä näkymättömäksi. Nikolas Rosen mu- 
kaan 1900-luvun hyvinvointivaltiomallin jälkeistä uusliberalistista hallintaa luonnehtii pyrkimys pidättäytyä aktiivisesta kansalaistensa holhoamisesta (Rose 1995; 1999). Se ei enää näe hyötyä eikä edes moraalista oikeutusta kansalaisia holhoavassa toiminnassa. Siksi se pyrkii näennäisesti vetäytymään yksityisen elämän alueelta ja luomaan mahdollisimman paljon tilaa yksilölliselle vapaudelle ja vastuulle. (Rinne 2004, 236238; Rose 1999, 49-50; 164-165; Edwards 2004) Tällä tavoin uusi hallinnan muoto tuottaa ratkaisun modernille dilemmalle hallinnan ja vapauden välillä, naamioimalla vallankäytön yksilöllisen autonomian ja valinnan vapauden tukemiseksi.

\section{Lopuksi}

On syytä huomata, että foucault'lainen näkökulma elinikäiseen oppimiseen ei ole varsinaisesti yhtenäinen valtateoria, vaan valta-analytiikkaa, joka mahdollistaa kuvauksen siitä, millä tavoin valta toimii yhteiskunnassa elinikäisen oppimisen diskursiivisten käytäntöjen kautta, tuottaen erilaisia subjektivaation tekniikoita ja muotoja (Wain 2004). Se ei myöskään ole ideologiakritiikkiä; se ei pyri paljastamaan väärää tietoisuutta tai osoittamaan suuntaa, josta vallaton, todellisen autonomian ja vapauden alue voisi löytyä. Sen sijaan foucault'lainen elinikäisen oppimisen analyysi on epäilyn politiikkaa, joka etsii vallankäyttöä juuri sieltä, jossa sen olemassaolo vahvimmin kielletään, tieteellisestä tutkimuksesta ja emansipatorisista käytänteistä. (Wain 2004)

Sen tehtävänä ei ole kritisoida hallintaa, vaan tehdä se näkyväksi monissa muodoissaan kriittisen keskustelun mahdollistamiseksi. Se tuo esiin elinikäisen oppimisen eräänlaisena hybridinä; intellektuaalisista, sosiaalisista ja materiaalisista tekniikoista koostuvana apparaattina, joka muokkaa inhimillisen toiminnan alueen näkyväksi ja hallittavaksi nykyiseen hallinnan mentaliteettiin sopivalla tavalla. Se toimii koulutuksen ja valtion hallinnan instituutioissa, mutta on lisäksi levinnyt laajalle yhteiskuntaan käsittäen myös kaikkein arkipäiväisimmät tilanteet, joissa yksilöt ymmärtävät itsensä ja kehittävät itseään elinikäisinä oppijoina.

Foucault'n ajatus hallinnan hajanaisuudesta ja monenkeskisyydestä. on siis otettava vakavasti. Siksi elinikäisen oppimisen ideologian kritiikin ei tulisi rajoittua vain OECD:n ja EU:n kaltais- ten, kieltämättä erittäin merkittävien instituutioiden ohjelmanjulistuksiin. Foucault'lainen analyysi läpäisee rakenne- ja yksilönäkökulmat; se rohkaisee etsimään hallintaa myös niitä paikoista ja käytänteistä, joissa elinikäisen oppimisen ohjelma materialisoituu ja muuttuu yksilöiden toiminnaksi. Sen avulla voidaan tarkastella, miten asiantuntijadiskurssit tuottavat yksilön itsearviointia, miten koko ihmiselämä, myös sen yksityinen ja näennäisen vapaa alue, tuodaan hallinnan kannalta funktionaalisten käytäntöjen kohteeksi.

\section{Lähteet}

Boud, D., Keogh, R. \& Walker, D. (1989). Promoting Reflection in Learning: a Model 18 -40. Teoksessa D.Boud, R. Keogh \& D. Walker (toim.) Reflection: Turning Experience Into Learning. London: Kogan Page. 7-17.

Brookfield, S.D. (2005). The Power of Critical Theory for Adult Learning and Teaching. Maidenhead: Open University Press.

Deleuze, G. (2005) Jälkikirjoitus kontrolliyhteiskuntiin. Teoksessa G. Deleuze. Haastatteluja. Tutkijaliitto. 115-127.

Dreyfus, H. \& Rabinow, P (1982). Michel Foucault: Beyond Structuralism and Hermeneutics. London: Harvester Wheatsheaf.

Edwards, R., Ranson, S. \& Strain, M. (2002). Reflexivity: Towards a Theory of Lifelong Learning. International Journal of Lifelong Education. 21 (6), 525-536.

Edwards, R. (2004). Intellectual Technologies in the Fashioning of Learning Societies. Educational Philosophy and Theory. 36 (1), 69-78.

Erlandson, P. (2005). The Body Disciplined: Rewriting Teaching Competence and the Doctrine of Reflection. Journal of Philosophy of Education. 39 (4), 661-670.

Fejes, A. (2005). New Wine in Old Skins: Changing Patterns in the Governing of the Adult Learner in Sweden. International Journal of Lifelong Education. 24 (1), 71-86.

Foucault, M. (1980). Tarkkailla ja rangaista. Otava.

Foucault, M. (1999). Seksuaalisuuden historia. Gaudeamus. 
Hacking, I. (2002) Historical Ontology. Cambridge: Harvard University Press.

Heikkinen, S., Silvonen, J. \& Simola, H. (1999). Technologies of Truth: Peeling Foucault's Triangular Onion. Discourse: Studies in the Cultural Politics of Education. 20 (1), 141157.

Helén. I. (2004). Hyvinvointi, vapaus ja elämän politiikka: foucaultlainen hallinnan analytiikka. Teoksessa Rahkonen, K. (toim.) Sosiologisia nykykeskusteluja. Gaudeamus.

Komiteanmietintö (1996). Elinikäinen oppiminen tietoyhteiskunnassa. Il osamietintö: strategiset valinnat. Koulutussuunnittelun neuvottelukunnan mietintö 1996:10.

Komiteanmietintö (1997). Oppimisen ilo: Kansallinen elinikäisen oppimisen strategia. Opetusministeriö. Elinikäisen oppimisen komitean mietintö. 1997: 14.

Jokisaari, O-J. (2004). Elinikäinen oppiminen häpeä ja menetetty vapaus. Aikuiskasvatus 24 (1), 4-16.

Lambeir, B. (2005). Education as Liberation: The Politics and Techniques of Lifelong Learning. Educational Philosophy and Theory. 37 (3), 349-355.

OECD (1996). Lifelong Learning for All. OECD.

Peters, M. (2001). Education, Enterprise Culture and the Entrepreneurial Self: A Foucauldian Perspective. Journal of Educational Enquiry. 2 (2), 58-71.

Popkewitz, T.S. (1999). A Social Epistemology of Educational Research. teoksessa T.S. Popkewitz \& L. Fendler (toim.) Critical Theories in Education: Changing Terrains of Knowledge and Politics. New York: Routledge. 17-44.

Rinne, R.(1998). From Labour to Learn: the Limits of Labour Society and the Possibilities of Learning Society. International Journal of Lifelong Education. 17 (2), 108-120.

Rinne, R. (2004). Elinikäisen oppimisen retoriikka ja koulutuspolitiikka. teoksessa $P$. Sallila (toim.) Elämänlaajuinen oppiminen ja aikuiskasvatus. Aikuiskasvatuksen 44. vuosikirja. Kansanvalistusseura ja Aikuiskasvatuksen Tutkimusseura. 219-246.

Rinne, R. \& Salmi, E.(1998) Oppimisen uusi järjestys. Vastapaino.
Rose, N. (1990) Governing the Soul: The Shaping of the Private Self. London: Routledge.

Rose, N. (1996) Inventing Our Selves: Psychology, Power and Personhood. Cambridge University Press.

Rose, N. (1995). Eriarvoisuus ja valta hyvinvointivaltion jälkeen. Teoksessa R. Eräsaari \& K. Rahkonen (toim.) Hyvinvointivaltion tragedia. Keskustelua eurooppalaisesta hyvinvointivaltiosta. Gaudeamus. 19-56.

Tennant, M. (1998). Adult Education as a Technology of the Self. International Journal of Lifelong Education. 17 (6), 364-376.

Tuomisto, J. (2002). Elinikäisen oppimisen retoriikka ja vallankäyttö. teoksessa R. Honkonen (toim.) Koulutuksen lumo. Tampere University Press. 15-34.

Tuomisto, J. (2004). Elinikäisen oppimisen toinen sukupolvi - unohtuiko jotain? teoksessa P. Sallila (toim.) Elämänlaajuinen oppiminen ja aikuiskasvatus. Aikuiskasvatuksen 44. vuosikirja. Kansanvalistusseura ja Aikuiskasvatuksen Tutkimusseura. 49-83.

Wain, K. (2004). The Learning Society in a Postmodern World. New York:Peter Lang.

Virtanen, A. (2006). Biopoliittisen talouden kritiikki. Helsinki School of Economics.

Värri, V-M. (2001). Kasvatus ja "ajan henki"tulkintoja psykokapitalismin armottomuudesta. Aikuiskasvatus 22 (2), 92-104.

\section{Viitteet}

1. On syytä huomauttaa, ettei Foucault tuotantonsa missään vaiheessa esitä varsinaista valtateoriaa. Sen sijaan hän puhuu valta-analytiikasta, heuristisesta tavasta hahmottaa yhteiskunnan strategisia voimasuhteita, erinäisiä hallinnan tekniikoita, päämääriä ja seurauksia. (Foucault 1999, 62-63; Helén 2005, 210)

2. Akseli Virtanen $(2006,254-255)$ puhuu Deleuzeen viitaten nykyisestä abstraktista ja henkisiin ominaisuuksiin kohdistuvasta vallasta mielivaltana. Veli-Matti Värri (2002, 97-98) puolestaan kutsuu tämänkaltaista markkinaperiaatteella toimivaa ja yksilön henkilökohtaisiin ominaisuuksiin kohdistuvaa hallinnan mentaliteettia osuvasti psykokapitalismiksi. 